\title{
Attitude of Teacher-Educators and Pupil-Teachers Towards the Two-Year B.Ed. Programme: A Review-Based Evaluation
}

\author{
Ajit Mondal (1) \\ Department of Education, West Bengal State University, Kolkata, West Bengal-700126, India
}

mondalajit.edn@gmail.com

ARTICLE INFORMATION

Received: July 14, 2020

Revised: August 08, 2020

Accepted: August 17, 2020

Published Online: October 21, 2020

\section{Keywords:}

Teacher Education, Teaching, Attitude, Teacher-Educators, Pupil Teachers, TwoYear B.Ed. \begin{abstract}
Background: The nitty-gritty of the teacher education chiefly rests on its curriculum implementation at institutional level, transaction in classrooms, assessment, evaluation, as well as the degree of its suitability. Thanks to the NCTE Regulations (Norms and Standards), 2014, the duration of the B. Ed. Programme has been extended from one year to two years across India from academic session 2015-16 to prepare the teachers professional and well-equipped with sound theoretical knowledge and pedagogical skills. However, the attitude of the teacher-educators and pupil teachers towards Two-Year B. Ed. Programme matters to a great extent for its assessing suitability of the new regulations.

Purpose: The present study has been undertaken to review only ten selective research studies only on the attitude of the teacher-educators and pupil-teachers towards the Two-Year B. Ed. Programme, aiming at grasping their attitudinal status or trend in a single frame with a broader spectrum of views value towards the Programme.

Methods: The review-based content analysis method was adopted and its approach was qualitative for analysing the attitude of the Teacher-Educators and Student-Teachers towards two-year B. Ed. Programme.

Results: the entire gamut of the Two-Year B. Ed. Programme under the NCTE Regulations, 2014 is effective and more promising for preparing professional and accountable teachers from the lens of the teacher-educators. Only the student-teachers need to be oriented with prescribed theoretical knowledge base through viable pedagogical strategies as most of the student-teachers have not hold favourable attitude towards the Two-Year B. Ed. Programme.

Conclusion: As a whole, the attitudinal trend among the teacher educators and pupil-students towards the two year B. Ed. Programme irrespective gender, locality, experience and types of institution hints at the pressing need to ensure that all the B. Ed. Institutions must comply with the norms and standards stipulated in the NCTE Regulations, 2014 for preparing professional and accountable teachers in the future ahead.
\end{abstract}

\section{Introduction}

Quality teachers are increasingly being seen as an essential to meet the ever changing demands of the society. Teacher education has thus gaining more concentration in the domain policy-formulation globally. Policymaking and regulatory issues in teacher education have direct implications on teacher education programmes.

Since the establishment of the National Council of Educational Research and Training (NCERT) in September 1961, the Teacher Education Department under NCERT started a number of teacher education programmes in terms of both number and variety were. A non-statutory National Council for Teacher
Education (NCTE) established in the Department of Teacher Education of the NCERT in 1973, made valuable contribution to the cause of teacher education in its own way. With the passing of the National Council for Teacher Education Act, 1993 (No. 73 of 1993) the NCTE started its maiden journey as a statutory body on $17^{\text {th }}$ August, 1995 to develop planned and harmonized expansion of the quality teacher education all over the nation and to control and sustain appropriately the rules and benchmarks in the teacher education programmes. Before the operation of the Regulations 2014, the NCTE crafted three consecutive regulations in 2005, 2007, and 2009 and each regulations is quite different from the preceding one. 


\section{Exploring the Journey towards Framing NCTE Regulations, 2014}

Though the justifications for formulating new regulations in 2014 have not been put in public by the NCTE, there were much talked about and debated in the domain of academia. Before the enactment of the NCTE new regulations, 2014, two landmark policy-related documents emerged in the landscape of school education in India and these have generated considerable implications for teacher education. These are the National Curriculum Framework 2005 (NCF) and the Right of Children to Free and Compulsory Education Act (RTE), 2009. The NCF-2005 reiterated the necessity for connecting knowledge to life outside the school, understanding about construction of knowledge, facilitating learner in knowledge construction, creating a fear free atmosphere, addressing diversity and inclusion, equity and quality (NCERT, 2015). Article 21A of the Constitution of India transformed elementary education in India from a justiciable right into a fundamental right of all the children belonging to the age-group of 6 to 14 and the RTE Act, 2009 mandates that the State shall provide quality and equitable education of eight years to all the children. It also stipulates norms and standards for each school and teachers' professional commitments. The Act prescribes comprehensive and continuous evaluation (CCE) of child's understanding of learning and his or her ability of its application. Besides, learning through discovery, activities and exploration in a child-centred manner has to be taken into consideration at the time of framing curriculum. Actually, Section 29 (1) of the RTE Act, 2009 clearly mandated that the academic authority, while laying down the curriculum and the evaluation procedure, shall take into consideration the following, namely:

a) conformity with the values enshrined in the Constitution;

b) all round development of the child;

c) building up child's knowledge, potentiality and talent;

d) development of physical and mental abilities to fullest extent;

e) learning through activities, discovery and exploration in a child friendly and child-centered manner;

f) medium of instructions shall as far as practicable, be in child's mother tongue;

g) making the child free of fear, trauma and anxiety and helping the child to express views freely; h) Comprehensive and continuous evaluation of child's understanding of knowledge and his or her ability to apply the same (MHRD, 2009).

On the other hand, the NCF, 2005 reiterated that "Teacher education must become more sensitive to the emerging demands from the school system. For this it must prepare the teacher for the roles of being an:

- encouraging, supportive and humane facilitator in teaching-learning situations to enable learners (students) to discover their talents, realise their physical and intellectual potentialities to the fullest, and to develop character and desirable social and human values to function as responsible citizens; and

- active member of a group of persons who makes a conscious effort for curricular renewal so that it is relevant to changing societal needs and the personal needs of learners" (NCF, 2005).

The NCF, 2005 also called for other emerging roles of teachers in line with the changing school context and the NCFTE, 2009 accordingly reiterated that

"The NCF requires a teacher to be a facilitator of children's learning in a manner that helps children to construct knowledge and meaning. The teacher in this process is a co-constructor of knowledge. It also opens out possibilities for the teacher to participate in the construction of syllabi, textbooks and teaching-learning materials. Such roles demand that teachers be equipped with an adequate understanding of curriculum, subject-content and pedagogy, on the one hand, and the community and school structures and management, on the other" (NCTE, 2009).

Consequently, both the NCF-2005 and the RTE Act, 2009 have made a paradigm shift in guidelines towards learner's construction of knowledge, learner's autonomy, curriculum content, pedagogy and formative assessment. In this backdrop, National Curriculum Framework for Teacher Education (NCFTE) - 2009 and Report of the Justice Verma Commission (JVC) in 2012 Report emerged to revamp teacher education in India.

National Curriculum Framework for Teacher Education (NCFTE), 2009 attempted to diminish the mismatch of theory and practice in teacher education programmes by incorporating the socio-cultural contexts of education, giving more emphasis on the 
field experience of student-teachers in all courses through practicum, pedagogy and learning, classroom based research, and internship of longer duration (NCERT, 2015).

Justice Verma Commission (JVC) was set up by the Ministry of Human Resource Department (MHRD), Government of India on $27^{\text {th }}$ June, 2011 under the chairmanship of Justice J.S. Verma, at the behest of the Hon'ble Supreme Court on $13^{\text {th }}$ May, 2011, primarily "to review whether the Regulations on Recognition Norms and Procedure, currently in force as laid down by the NCTE are being properly enforced. If not, how to evolve a fair and transparent manner in which these norms and standards may be enforced" (MHRD, 2012). The JVC made recommendations which paved the way to formulation of the NCTE Regulations, 2014 in the near future that

"Teacher education should be a part of the higher education system. The duration of programme of teacher education needs to be enhanced, in keeping with the recommendations of the Education Commission (1966), the implementation of which is long overdue (ibid, p. 95).

"Current teacher education programmes may be re-designed keeping in view the recommendations in the National Curriculum Framework for Teacher Education (NCFTE, 2009) and other relevant material" (ibid, 2012).

After the submission of the JVC Report, the Supreme Court constituted a committee to develop an action plan that outlines the processes and timelines required for the implementation of the recommendations. Following this action plan, NCTE constituted various subcommittees, including subcommittees for designing curriculum frameworks for various teacher education programmes, to work on the different recommendations (Sharma, 2019). This effort ultimately contributed to the final shape of the National Council for Teacher Education (Recognition Norma and Procedure) Regulations, 2014 and accordingly, the National Council for Teacher Education (Recognition Norms and Procedure) Regulations, 2014 was published in Gazette of India on $28^{\text {th }}$ November, 2014 vide Notification
No. F 51-1/2014-NCTE (N\&S). In the present regulations, a number of changes in areas of duration of programmes and intuitional norms and standards have been taken place. Among the other changes, the enhancement of duration of the B.Ed., B.P.Ed. and M.Ed programmes have been conspicuously made from one year to two years from the academic session 2015-16 onwards. The new Regulations specifically mandated that "The B.Ed. programme shall be of duration of two academic years, which can be completed in a maximum of three years from the date of admission to the programme (Government of India, 2014).

\section{Emerging Opportunities and Challenges Under the Two-Year B.Ed. Programme}

The National Council for Teacher Education (Recognition Norms and Procedure) Regulations, 2014 issued norms and standards of total fifteen teacher education programmes in Indian Territory. Each institute must comply with the prescribed norms and standards for offering any programme among these. Out fifteen programmes of teacher education, B.Ed. programme is much-needed one as it offers a broad coverage of preparing teachers in terms of number of classes. According to the NCTE Regulations, 2014,

\begin{abstract}
"The Bachelor of Education programme, generally known as B.Ed., is a professional course that prepares teachers for upper primary or middle level (classes VI-VIII), secondary level (classes IX-X) and senior secondary level (classes XI-XII). There shall be at least two hundred working days each year exclusive of the period of examination and admission. The institution shall work for a minimum of thirty six hours in a week (five or six days) during which physical presence in the institution of all the teachers and student teachers is necessary to ensure their availability for advice, guidance, dialogue and consultation as and when needed and the minimum attendance of the student-teachers shall have to be $80 \%$ for all course work and practicum, and 90\% for school internship" (Government of India, 2014).
\end{abstract}

The new regulations also made a change by incorporating a number of new subjects in the curriculum. The B.Ed. curriculum has been designed to integrate the 
study of subject knowledge, human development, and pedagogical knowledge and communication skills. The Two-Year B.Ed. programme comprises three broad curricular areas: Theory Courses (Perspectives in Education and Curriculum \& Pedagogic Studies), Engagement with the Field (Government of India, 2014).

Among these three broad curricular areas, 'Engagement with the Field' (Practicum) validates theoretical and pedagogical knowledge with practice in real classroom. According to the NCTE Regulations, 2014

"The B.Ed. Programme provides sustained engagement with the Self, the Child, the Community and the School, at different levels and through establishing close connections between different curricular areas. This curricular area would serve as an important link between the above two broad curricular areas ((Perspectives in Education and Curriculum \& Pedagogic Studies) through its three components: (a) Tasks and Assignments that run through all the courses, (b) School Internship and (c) Courses on Enhancing Professional Capacities" (Government of India, 2014).

The above two broad curricular areas are amalgamated with the field engagements through different tasks and projects with the community, the school, and the child in school and out-of-school. These tasks and projects would help in substantiating perspectives and theoretical frameworks studied in a teacher education classroom with field-based experiences (Government of India, 2014). The NCTE Regulations 2014 reiterated that 'School internship' is a part of the broad curricular area of 'Engagement with the Field' to be organized for 4 weeks in the first year and 16 weeks in the final year of the course in order to develop a broad repertoire of perspectives, professional capacities, teacher sensibilities and skills. Internship in schools also includes, besides practice teaching, an initial phase of one week for observing a regular classroom with a regular teacher and incorporates peer observation, teacher observation and faculty observations of practice lessons (Government of India, 2014).

In a nutshell, the Two-Year B.Ed. Programme as suggested by the NCTE Regulations, 2014 now intends to move towards preparing professional and humane teachers. The 2014- Regulations also imply that in the rapidly changing society driven by science and technology, teachers need to be professional and wellequipped with sound theoretical content knowledge and pedagogical skills and ethical values. On the other hand, researcher is of the views that B.Ed. programme being a professional course needs acquisition of learner-centric teaching skills and strategies more than extensive theoretical knowledge of different subjects. Few emerging subjects (Inclusive Education, ICT, etc.) and 'study of child, child development and adolescence' have been reasonably incorporated in the curriculum. But there remain a number of subjects for which both the pupil teachers and teacher educators are losing attraction of the course. In the near future, its goals may be immaterialised. However, the attitude of the teacher-educators and pupil teachers towards Two-Year B.Ed. Programme matters to a greater extent for its successful implementation. In this backdrop, the present study has been undertaken to examine the status or trend of attitude of teacher-educators and pupil teachers towards Two-Year B.Ed. Programme in India with reference to NCTE Regulations, 2014 after reviewing existing literature related to the study.

\section{Rationale of the Study: Exploring Some Implications}

After the enforcement of the NCTE Regulations, 2014, B.Ed. Programme became of Two-Year across India and it also came into operation from the academic session 2015-2016 in India. The Regulations entail norms for infrastructure, fees, intake, eligibility of students and teachers, working days and hours, besides curriculum, programme implementation and assessment (Singh \& Tayeng, 2019). Apart from theory courses, it also puts emphasis on professional exposure and experiences through 20 weeks internship in schools. It is hoped that the Two-Year B.Ed. programme will enhance the cognitive base, professional commitment, pedagogical skills and competency and social status of teachers in matching with rapidly changing society. However, attitude and opinion of stakeholders is very important for assessing relevance and suitability of new regulations as well as its appropriate implementation. Positive attitude among the teachers and the taught is also necessitated for ensuring effective out-comes of the programme. In the sphere of teacher education, 
the attitude forms a significant and broad aspect that prompts outlook on multiple factors related to the TwoYear teacher education programme. The favourable attitude of the student-teachers and teacher-educators towards the new programme is highly necessitated for preparing quality professional teachers. Considering this perspective the researcher made up his mind to examine the attitude of the teacher-educators and trainee-teachers Two-Year B.Ed. Programme.

\section{Research Questions}

In connection with the above-cited objectives of the study, the following research questions emerged in the mind of the researcher.

1) What type of attitude of the teacher-educators was towards Two-Year B. Ed. Programme in India irrespective of gender, type of institution, teaching experience and locality with reference to the NCTE Regulations, 2014?

2) What type of attitude of the pupil-teachers was towards Two-Year B. Ed. Programme in India irrespective of gender, type of institution and locality with reference to the NCTE Regulations, 2014? and

3) What was the trend of attitude between the teachereducators and pupil-teachers towards Two-Year B. Ed. Programme in India irrespective of gender, type of institution and locality with reference to the NCTE Regulations, 2014?

\section{Materials and Methods}

To conduct the present study the researcher adopted the review-based content analysis method and its approach was qualitative for analysing the attitude of the Teacher-Educators and Student-Teachers towards Two-Year B.Ed. Programme. By analytically evaluating qualitative data embedded within the texts in an objective manner can be transformed into quantitative data. Content analysis stands in the crossing point of observation and document analysis. Dr. Klaus Krippendorf (1993) defined content analysis as "a research technique for making replicable and valid inferences from texts (or other meaningful matter) to the contexts of their use" (p.18). The Data or information of the present study has been taken from various research papers and curriculum frameworks for teacher education (NCFTEs) and Regulations framed by the NCTE. Ten (10) Research Papers published in different research journals between 2016 and 2019 on the attitude of teacher-educators and pupil teachers towards Two-Year B.Ed. Programme in India with reference to the NCTE Regulations, 2014 were taken as sample for the present study.

\section{Current Attitudinal Studies on the Two-Year B.Ed. Programme}

A good number of researchers have already examined the attitude of teachers-educators and trainee-teachers towards the Two-Year B.Ed. programme in India since the implementation of the NCTE New Regulation 2014. Though there still needs studies more on TwoYear B.Ed. programme in India for assessing the suitability of enhancing the duration of the Programme from one to Two-Year, the researcher has thought of exploring the consolidated trend about the attitude of the teachers from the existing research literature. What the current research literature revealed about the attitude of teachers towards the programme. However, for the purpose of the present study, the researcher has only taken the following ten research papers pertaining to the attitude towards Two-Year B.Ed. Programme for assessing the practicability of extension of the Programme from one to Two-Year.

Singh \& Tayeng (2019) made a study to measure the attitude of teacher-educators and students of B.Ed. colleges affiliated to Rajiv Gandhi University of Arunachal Pradesh towards existing Two-Year B.Ed. programme. The researchers employed descriptive-cum survey method and used self made attitude scale based on Likert's five points Scale, for the collection of data. The findings of the study revealed that the attitude of the teacher-educators is more favourable than the B.Ed. students towards Two-Year B.Ed. programme. The attitude of female B.Ed. students is higher than male B.Ed. students. There is no significant difference found in the attitude of Government and private B.Ed. students; tribal and non-tribal B.Ed. students towards Two-Year B.Ed. programme. Finally, it can be concluded that, the teacher-educators and B.Ed. students both have favourable attitude towards TwoYear B.Ed. programme.

Vijayalakshmi \& Menon (2017) conducted a study to determine the perspective of teacher educators and teaching competencies for imparting Two Year 
B.Ed Programme suggested by NCTE in Karnataka. In this study, teaching perspectives meant to assess the teacher's views and attitudes towards the newly implemented Two-Year B.Ed. programme suggested by NCTE across Karnataka and teaching competency referred to the competency level of the teacher educators. The survey method was adopted for the study. The Teacher Educators Perspectives Scale and Teaching Competency Scale were used for collecting the data from the Teacher Educators. A sample size for this study included 100 Teacher Educators from B.Ed. colleges in the District Mysuru (Mysore) of Karnataka. The study revealed that the level of Teacher Educators' perspective towards Two-Year B.Ed course was at a moderate level and their competency level was at a high level. It also found that there was a positive correlation between Teacher Educators' perspective towards TwoYear B.Ed. course and Teacher Educators' competency level, hence the hypotheses are accepted.

Sao \& Behera (2016) undertook a study to estimate the student-teachers' attitude towards Two-Year B.Ed. Programme with reference to NCTE Regulation, 2014 in Purulia District of West Bengal. Using Purposive sampling technique, two hundred and sixty (260) Student-Teachers of one Govt. Sponsored (57) and three Self-Financing / Private (203) B.Ed. Colleges (both Urban and Rural areas) affiliated to SidhoKanho-Birsha University in Purulia District of West Bengal were taken as representative sample and for selecting the student-teachers Stratified Random Sampling was adopted. An attitude scale (Likert Type) was used for knowing the attitude of the B.Ed. student-teachers towards Two-Year B.Ed. Programme. The major findings of this study revealed that the attitude of B.Ed. Student-Teachers in Purulia District of West Bengal was neither more favourable nor unfavourable towards Two-Year B.Ed. programme i.e., satisfactory or average in attitude towards Two-Year B.Ed. programme.

Sudha (2017) undertook a study to assess the attitude of student teachers and teacher-educators towards Two-Year B.Ed. Course in Tamilnadu with reference to locality, level of experience, gender, and type of institution. An opinionnaire comprising 25 statements were administered to the student trainees and teacher educators and administering Likert type scale their opinions were quantified. The sample consisted of
50 male student trainees and 50 female student trainees and More than 30 male teacher educators and female educators selected from two government/ two government aided/two private colleges in Tamilnadu were included in the sample of the study. The study explored that there was no significant difference among teacher trainees with reference to locality, level of education but there was significant difference with respect of gender and there was no significant difference among teacher educators with respect to level of experience and locality. It also revealed that there was no relationship between attitude of teacher-educators and teacher trainees because teacher-educators felt that TwoYear B.Ed. course would be good for the students and teacher trainees did not want to study for two years. This study finally brought to light that the Two-Year B.Ed. course was not preferred by teacher trainees but it was welcomed by teacher-educators. So, the study inferred that the teacher-educators had positive attitude towards the programme than the teacher trainees.

Khanna \& Pandey (2014) conducted a comparative study on attitude of teacher educators and stakeholders towards NCTE regulations 2014. A pilot study was carried out for selecting a sample of 200 (100 male and 100 female) teacher educators and 20 stakeholders of teacher education from colleges located in Faridabad District of Haryana. The present research was a descriptive in nature. Teacher Educators' attitude scale towards NCTE Regulations 2014 and Stakeholders' attitude scale towards NCTE Regulations 2014 were developed and standardized separately by the researcher herself for the collection of data. The findings revealed that majority of the Teacher educators and stakeholders of Faridabad District of Haryana had moderate level of attitude towards NCTE Regulations 2014. The Teacher Educators and the stakeholders differed significantly in their attitude towards NCTE Regulations 2014.

Adhikary (2017) conducted an investigation to study the perception of the Teacher trainees towards Two Year B.Ed. Programme in Assam. The methodology adopted for the study was descriptive in nature. For the present study 100 teacher trainees as sample were taken randomly from different B.Ed. colleges of Assam of which 50 male trainees and 50 female trainees were selected for the study. For purposes of collection of Primary data a set of well structured Questionnaire based on five points Likert Scale was used. The 
findings revealed that the most of the teacher trainees had negative perception towards the Two-Year B.Ed. programme due to lack of its economic affordability and were dissatisfied with the curriculum distribution of the Two-Year B.Ed. program. Teaching for four months in school under the Internship Programme without any remuneration and lack of job security after completion of Two-Year long course are also the factors of disinterest to this programme.

Pakira \& Khan (2018) made an attempt to study the student-teachers' attitude towards Two-Year B.Ed. Programme with special reference to NCTE New Regulation, 2014 in West Bengal. 110 StudentTeachers from different Govt. Sponsored and Self Financing / Private B.Ed. Colleges (both Urban and Rural areas) affiliated to WBUTTPA, University of Calutta, Burdwan University of West Bengal were taken as sample for the study. Purposive sampling technique was adopted for selecting the B.Ed. Colleges. For selecting the student teachers stratified random sampling was adopted. A self-developed perception scale on effectiveness of Two-Year B.Ed. Programme was used for collecting the data. Findings of the study showed that most (90.9\%) of the trainee teachers has moderate perception towards Two-Year B.Ed. programme. The study revealed that there was no significant difference in the perception of trainee teachers towards the Two-Year B.Ed. programme with regard to their Educational Qualification, Caste, Habitat, Status of Training (pre-service and in-service) and there was significant difference in perception between married and un-married trainee teachers towards Two-Year B.Ed. programme. Un-married trainee teachers possessed more favourable perception towards Two-Year B.Ed. programme.

Gorain (2017) made an attempt to study the B.Ed. teacher educators' attitude towards Two-Year B.Ed. Programme in Birbhum and Bardhaman Districts of West Bengal. Total 40 teacher educators teaching in government and private B.Ed. institutions in Birbhum $\&$ Burdwan Districts were selected by random sampling technique. Descriptive Survey Method was used in the study and a self-constructed questionnaire was prepared by researcher for data collection. The study revealed that attitude of the teacher educators irrespective of gender and locality in Birbhum and Bardhaman Districts of West Bengal towards Two Year B.Ed. Programme did not differ significantly. It also found that more than
$50 \%$ of the respondents agreed towards Two-Year B.Ed. programme and $52.50 \%$ of the respondents opined that the duration of one-year B.Ed. Programme was not sufficient time for preparing a trained teacher.

Mahato \& Behera (2018) made an investigation to know the attitude of the student-teachers towards Practicum, an essential part of the Two-Year B.Ed. Programme in Purulia District of West Bengal. Total 250 Student-Teachers from one Govt. Sponsored (47) and four Self Financing / Private (203) B.Ed. Colleges (both Urban and Rural areas) in Purulia District of West Bengal were taken as sample for the study. For selecting the student- teachers stratified random sampling was adopted and an attitude scale (Likert Type) was used for measuring the attitude of the B.Ed. student-teachers towards Practicum. The study revealed that the attitude of B.Ed. Student-Teachers in Purulia District of West Bengal was neither more favourable nor unfavourable towards Practicum i.e., satisfactory or average in attitude. The study also revealed that attitude of B.Ed. student-teachers towards practicum with reference to Male and Female, Rural and Urban, as well as Govt. Sponsored and Private towards Practicum differed significantly.

Prakash (2019) conducted a study to find out the attitude towards two year B.Ed. programme of student teachers with regard to their locality and type of family in Tamilnadu. Survey method was used for the investigation. 30 student teachers from B.Ed., College of Dindigul District, Tamilnadu were used as sample for the study. The investigator adopted the Attitude Scale towards two year B.Ed., programme developed and validated by V. Rajeswari and P. Shanmugavadivu (2015). The study revealed that there was significant difference between rural and urban student teachers. The urban student teachers had better attitude towards Two-Year B.Ed. Programme. It also explored that there was significant difference between nuclear and joint family student teachers. It found out that the joint family student teachers had better attitude towards Two-Year B.Ed. Programme.

\section{Findings, Discussion and Recommendations}

The above cited investigations on the attitude of the teacher-educators and pupil teachers towards Two-Year B.Ed. programme in India have been conducted mainly in relation with their gender, locale backgrounds, teaching experience and type of institutions. Reviewing 
the findings of the ten research studies, the status or trend of attitude of the teacher-educators and studentteachers towards the Two-Year B.Ed. Programme with reference to the NCTE Regulations, 2014 can be summarily shown in the following Graph-1:

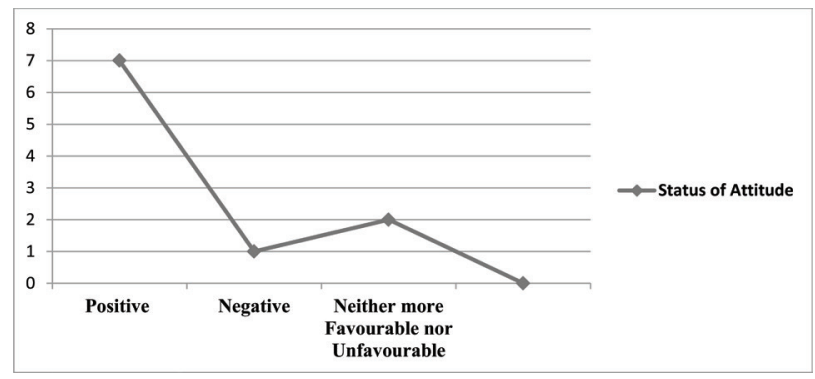

Graph 1: Status of Attitude of the Teacher-Educators \& StudentTeachers towards the Programme.

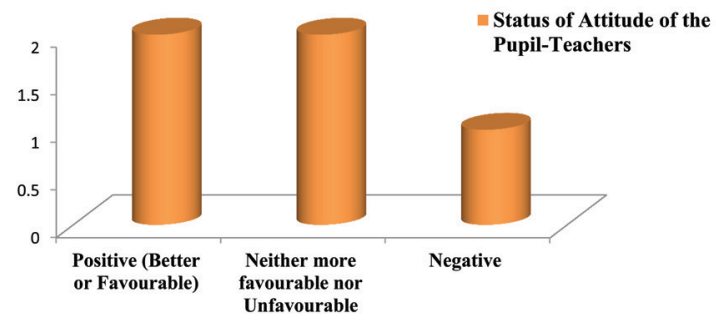

Figure 1: Status of Attitude of the Pupil-Teachers towards TwoYear B.Ed. Programme.

The following inferences can be drawn from the consolidated findings:

- Only five of out of ten studies dealt with the attitude of teacher-educators towards Two-Year B.Ed. Programme with reference to the NCTE Regulations, 2014. These revealed that the teacher-educators had positive attitude or favourable attitude towards the programme. Their attitude implied that extension of duration of the B.Ed. programme is highly pertinent for equipping the pupil teachers with cognitive base as well as pedagogical skills.

- Other five among the ten studies dealt with the attitude of student-teachers towards Two-Year B.Ed. Programme with reference to the NCTE Regulations, 2014. Only two out of the five studies revealed that the studentteachers hold better or moderate attitude towards the programme. Only two out the five studies revealed that the student-teachers had neither more favourable nor unfavourable attitude towards the programme. Only one among the five studies revealed that studentteachers had negative or unfavourable attitude towards the programme. The findings in this segment are diverse in nature in terms of direction towards suitability of the extension of duration of the programme. The diverse attitude among the pupil teachers indicates an area of concern which must fall under scrutiny of policyformulation.

- As a whole, seven out of ten studies revealed that the teacher-educators and student-teachers had positive attitude towards the programme. However, the teachereducators had showed positive attitude more than the student-teachers. Both the negative and oscillating (neither more favourable nor unfavourable) attitude of the trainee-teachers is detrimental to effective implementation towards preparing quality professional teachers. The very purpose of extension of duration will be futile without ensuring favourable attitude of the trainee-teachers who are in the heart of the NCTE Regulations, 2014.

Considering all the findings of the studies, it can safely be inferred that the entire gamut of the TwoYear B.Ed. Programme under the NCTE Regulations, 2014 is effective and more promising for preparing professional and accountable teachers from the lens of the teacher-educators. Only the student-teachers need to be oriented with prescribed theoretical knowledge base through viable pedagogical strategies as most of the student-teachers have not hold favourable attitude towards the Two-Year B.Ed. Programme. The B.Ed. intuitions need to pay attention more and more to the student supportive environment and availability of library resources, ensuring requite number of quality teacher-educators and using ICT in teachinglearning process for developing suitable attitude among the student-teachers towards the Two-Year B.Ed. Programme. Classroom practice should be able motivate the trainee-teachers to 'engage with teaching as a practical and social activity'. In India, currently close to 90 percent of pre-service teacher training institutions are in the private sector (MHRD, 2012). Both Central and State Governments should make inspection or sudden visit on regular basis at all the teacher education institutes for maintaining all quality norms prescribed by the NCTE Regulations, 2014.

As a whole, the attitudinal trend among the teacher educators and pupil-students towards the two year B.Ed. Programme irrespective gender, locality, experience and types of institution hints at the pressing need to ensure that all the B.Ed. Institutions must comply with the norms and standards stipulated in the NCTE 
Regulations, 2014 for preparing professional and accountable teachers in the future ahead. Rapid growth of B.Ed. colleges without fulfilling the NCTE norms and standards throughout the academic session has been further deteriorating the quality of teacher education. On getting final approval in the form 'Recognition' from both the NCTE and State Government before the commencement of B.Ed. programme, most of the institutions don't maintain the prescribed norms, particularly retention of the teacher-educators who had been appointed at the beginning. Recruitment of Teacher-educators in the private institutions is a daily affair. Quality teacher-educators have been succumbed to the low quality teacher-educators due to availability of M.Ed. holders in the market.

Moreover, the schools for practice teaching should be close to the institution, so that practice teaching programme can be conducted in better way. The extension of duration of B.Ed. programme with 16 weeks internship by NCTE will then have rationality. Otherwise, the prevalence of negative attitude among the trainee-teachers towards Two-Year B.Ed. Programme will make a bad impact on building a positive attitude towards teaching profession in future ahead. Moreover, it will lead to the decline of students' enrolment and possibility of shutting down of many B.Ed. institutions in India. So, the policymakers under the ambit of the NCTE should also conduct a comprehensive study, seek stakeholders' opinion and make observations across the country for judging the effectiveness of the extension of duration of the programme.

The NCTE has to play the roles beyond the roles embedded in the NCTE Act, 1993 in line with demands of the changing society. The NCTE has also to be empowered and active more in terms of sharing knowledge resources on teacher education. The NCTE should promote and conduct innovation and research in various areas of teacher education at grass root levels and disseminate the results among the teacher-educators. It should also publish teachers' guide books or resource books or Toolkits on curriculum frameworks, Internship, Practicum etc. It is difficult to think that the NCTE still relies on the Department of Teacher Education under the NCERT for dissemination of research in teacher education and publication of books, modules, e-content and training materials on teacher education. The Journals published from the NCTE will have to be regular and these should be easily accessible to all through NCTE website. Lastly, the NCTE should make provisions for granting financial assistance for organizing workshop, seminars and conferences and research projects. Otherwise, the apprehension articulated in the University Education Commission (194849) Report "People in this country have been slow to recognize that education is a profession for which intensive preparation is necessary as it is in any other profession" (Government of India, 1949) will remain in the future ahead.

After reviewing the existing literature on the attitude towards Two-Year B.Ed. programme, it can also be remarked that there exist few loopholes in the programme. As for example, the regulations of NCTE with reference to the internship of 16 weeks during the second year are too tedious and involuntary. Teacher education primarily consists of sets of events projected to equip student-teachers with some teaching skills, attitudes, cognitive base, behaviour, self-confidence, professionalism, values, accountability etc which are greatly necessitated for adopting teaching as a profession. Change in the attitudinal level and mindsets of the pupil-teachers and teacher-educators towards any teacher education programme mandated by the NCTE needs to be ensured first for preparing quality teachers in the classrooms where the future of India is being formed.

\section{Acknowledgements}

The Author expressed thanks to the authority of the West Bengal State University, West Bengal for providing encouragement and academic support for such research work.

\section{Authorship Contribution}

The author claimed authorship as a sole contributor.

\section{Funding}

The author(s) received no financial support for the research, authorship, and/or publication of this article.

\section{Conflict of Interest}

The author(s) declared no potential conflicts of interest with respect to the research, authorship, and/ or publication of this article. 


\section{References}

Adhikary, A. (2017). A Study on the Perception of the Teacher Trainees towards Two Year B.Ed. Programme Implemented in the Teacher Education Institutions in Assam. International Journal of Scientific and Research Publications, 7(9), 385-388.

Gorain, R. (2017). Views of Teacher educators towards TwoYear B.Ed. Programme of West Bengal. International Journal of Interdisciplinary and Multidisciplinary Studies (IJIMS), 4(2), 95-98.

Government of India (1949). The Report of the University Education Commission (1948-49). Delhi: Government of India.

Government of India (2007). The Constitution of India. New Delhi: Ministry of Law and Justice, Government of India.

Government of India (2014). The National Council for Teacher Education (Recognition Norms and procedure) Regulations, 2014 vide Notification No. F 51-1/2014-NCTE (N\&S) in Gazette of India dated $28^{\text {th }}$ November, 2014. New Delhi: Gazette of India, Government of India.

Khanna, S., \& Pandey, S. (2014). A comparative study of attitude of teacher educators and stakeholders towards NCTE regulations 2014. International Journal of Academic Research and Development, 3(4), 29-34.

Krippendorff, K. (2004). Content Analysis: An Introduction to Its Methodology (2 ${ }^{\text {nd }}$ ed.). Thousand Oaks, California: SAGE Publications, Inc.

Mahato, A., \& Behera, S.K. (2018). Attitude of B.Ed. Student-Teachers towards Practicum. American Research Journal of Humanities and Social Sciences, 4, 1-13. https://doi.org/10.21694/2378-7031.18004

MHRD (2009). The Right of Children to Free and Compulsory Education Act, 2009. New Delhi: MHRD, GOI.

MHRD (2012). Vision of Teacher Education in India Quality and Regulatory Perspective: Report of the High-Powered Commission on Teacher Education Constituted by the Hon'ble Supreme Court of India, Volume 1 (Verma Committee). New Delhi: Department of School Education and Literacy, MHRD, Government of India.
National Council for Teacher Education (2009). National Curriculum Framework for Teacher Education Towards Preparing Professional and Humane Teacher (NCFTE, 2009). New Delhi: Government of India, National Council for Teacher Education (NCTE).

NCERT (2005). National Curriculum Framework (NCF), 2005. New Delhi: National Council of Educational Research and Training (NCERT), MHRD, GOI.

NCERT (2015). Syllabus for Bachelor of Education (B.Ed.) Programme. New Delhi: Department of Teacher Education, National Council of Educational Research and Training (NCERT), MHRD. GOI.

Pakira, J. \& Khan, S. (2018). Perception of Trainee Teachers towards Two-Year B.Ed. Programme with Respect to Some Determinants. Online International Interdisciplinary Research Journal, 8, 36-44.

Prakash (2009). Attitude towards Two Year B.Ed. Programme of Student Teachers. Thiagarajar College of Preceptors Edu Spectra Online Journal, 1(2), 9-12

Sao, S., \& Behera, S.K. (2016). Student-teachers' Attitude towards Two-Year B.Ed. Programme with reference to NCTE Regulation, 2014. Pedagogy of Learning, 2(3), 9-24.

Sharma, G. (2019). Policy and Regularity Changes in Teacher Education in India: Concerns, Debates and Contestations. Economic \& Political Weekly, 54(9), $02 \mathrm{Mar}, 2019$. Retrieved from https://www.epw.in/ engage/article/policy-and-regulatory-changes-teachereducation-in-india

Singh, V., \& Tayeng, G. (2019). Attitude of TeacherEducators and B.Ed. Students towards Two-Year B.Ed. Programme in Arunachal Pradesh. Voices of Teachers and Teacher Educators, VII(II), 119-125.

Sudha, S. (2017). Attitude of Student Teachers and Teacher Educators towards Two Years B.Ed. Course. PARIPEX - Indian Journal of Research, 6(1), 212-114. https:// www.doi.org/10.36106/paripex

Vijayalakshmi, M.K., \&Menon, R.B. (2017). The Perspective of Teacher Educators and Teaching Competencies for Imparting Two Year B.Ed Programme Suggested by NCTE in Karnataka. IOSR Journal of Business and Management (IOSR-JBM), (Issue - April 2017), 51-54. 


\section{Issues and Ideas in Education}

Chitkara University, Saraswati Kendra, SCO 160-161, Sector 9-C, Chandigarh, 160009, India

Volume 8, Issue 2

September 2020

ISSN 2320-7655

Copyright: [ $(2020$ Ajit Mondal] This is an Open Access article published in Issues and Ideas in Education (Issues Ideas Educ.) by Chitkara University Publications. It is published with a Creative Commons AttributionCC-BY 4.0 International License. This license permits unrestricted use, distribution, and reproduction in any medium, provided the original author and source are credited. 